\title{
Attitudes of Libyan Retail Consumers toward Islamic Methods of Finance
}

\author{
Alsadek Gait \\ Accounting, Finance and Economics \\ Griffith University \\ Australia \\ Andrew Worthington \\ Accounting, Finance and Economics \\ Griffith University \\ Australia
}

Purpose - Analyse the attitudes of Libyan retail customers to Islamic methods of finance.

Design/methodology/approach - Survey of 385 Libyan retail consumers. Descriptive, factor and discriminant analysis of responses to identify principal factors affecting attitudes to and the potential use of Islamic financial products and services.

Findings - The results indicate that while most respondents have at least some knowledge about some Islamic products, especially Musharakah (full-equity business partnerships) and Quard Hassan (interest-free benevolent loans), they are generally unaware of many other products. Nonetheless, most respondents (85.9\%) are potential users of Islamic methods of finance at the retail level, though potential use varying markedly according to age, level of education, employment, income and nationality. Factor analysis reduces the large number of variables that determine retail consumers' attitudes towards Islamic methods of finance to just community service, profitability, religion and unique services. Discriminant analysis shows that religion and community service are the most important positive attitudes determining the potential use of Islamic methods of finance by retail consumers in Libya.

Research limitations/implications - Undertaken in a single national context, so no possibility of comparing the results with alternative financial systems in different stages of the adoption of Islamic finance. Research completed in 2010, with the ongoing unrest in Libya precluding publication until recently.

Practical implications - Religious motivations rank highest in determining positive attitudes to Islamic methods of finance, and marketers should ensure that Islamic financial products and services strictly comply with Sharia. However, it may be possible to strengthen these positive attitudes by promoting that the community service role of Islamic finance is also important. Consumers also react favourably to marketing that either admits something negative about the product (e.g., Islamic finance is Sharia compliant, but less profitable for depositors) or something positive about a competing product (e.g., conventional finance is more profitable, but cares less about the community). Marketers should emphasize the strengths of Islamic finance across the several sources of positive attitudes we have identified.

Originality/value - There is no published work on Libyan retail consumers and limited study of attitudes toward Islamic methods of finance more generally.

Keywords - Islamic methods of finance, Islamic banking, consumer attitudes

Paper type - Research paper 


\section{Introduction}

Islamic finance-financial institutions, products, and services designed to comply with the central tenets of Sharia (Islamic law) — is one of the most rapidly growing segments of the global finance industry. Starting with the Dubai Islamic Bank in 1975 (and operations in the United Arab Emirates, Egypt, the Cayman Islands, Sudan, Lebanon, the Bahamas, Bosnia, Bahrain and Pakistan), the global market for Islamic financial services reached US $\$ 951$ billion in 2008, up from US\$758 billion in 2007, and US\$549 billion in 2006 (IFSR, 2010). Of this, commercial banks account for most Sharia-compliant assets, followed by investment banks, Sukuk (bonds), managed funds, and Takaful (insurance). The key Islamic finance centres are currently concentrated in the Middle East (including Iran, Saudi Arabia, Kuwait, the United Arab Emirates and Bahrain), in Asia (especially Malaysia, but also Bangladesh, Pakistan and Indonesia), as well as in North Africa (Sudan and Egypt). However, there is also a sizeable and rapidly growing Islamic finance presence in a number of Western economies, including 22 Sharia-compliant banks or banking windows in the UK, 9 in the US and 4 in Australia (IFSR, 2010).

Importantly, while the practice of Islamic finance is centuries old, only recently have Islamic financial institutions offering Sharia-compliant products and services become more widespread and important. Indeed, even in predominately-Muslim countries, it is only in the last few years that Islamic finance products and services have directly competed with their 'conventional' counterparts. Clearly, as Islamic products and services enter these markets, an important consideration is the attitudes of consumers towards these new methods of finance (Gait and Worthington 2008), as these determine the extent to which consumers choose to patronize these alternative products and services, with consumer attitudes being the key drivers of behavioural change in terms of purchases. Key concerns include the influence of religious beliefs and the relative pricing, costs and benefits, convenience and access to Islamic financial products and services vis-à-vis conventional bank products and services. For conventional financial institutions, the presence of financial institutions offering Islamic financial products and services may also affect their competitive position and marketing strategies. It may also influence any decisions they may make to introduce Sharia-compliant products and services themselves.

We believe Libya provides an interesting context to examine these issues. First, while the majority of the Libyan population are Muslims, there are presently no Islamic financial 
institutions operating in Libya. Second, the Libyan government is increasingly moving towards the liberalisation and reform of the country's financial system and part of this process foresees the contribution of Islamic financial institutions, products and services. Finally, there is no published work on Libyan retail consumers and limited international study of attitudes towards Islamic methods of finance more generally. This purpose of this paper is then to provide the results of a survey of Libyan retail consumers on their attitudes towards Islamic methods of finance.

Certainly, progress toward the development of an Islamic banking and finance industry in Libya is rapidly accelerating, especially since 2011 with the ousting and death of the country's former leader, Muammar Gaddafi, and the collapse of his 42-year "First of September 'Al Fateh' Revolution” and the 34-year-old Jamahiriya state. Under the old regime, even though Libyan Civil Law No. 74 prohibited Riba (interest) as did Civil Law No. 86 for Gharar (uncertainty) as long ago as the early 1970s, few legal mechanisms existed in Libya facilitating the introduction of Islamic banking and finance products and services. However, Banking Law No. 1 in 2005 technically eased the granting of licenses for banks, potentially including Islamic banks, and a subsequent amendment by the National Transitional Council (NTC) as Law No. 46 in 2012 provides a detailed section on Islamic banking. This includes the definitions of an Islamic Bank, Islamic Banking, the Central Shariah Advisory Board in the Central Bank, the Shariah Advisory Board(s) for Islamic Bank(s), Shariah Auditing administration, Islamic banking branches, and Islamic banking windows. With power transferred from the NTC to the newly elected General National Congress on 8 August 2012, the future of Islamic banking and finance in Libya now appears promising, as the central monetary authority is now directly involved in its development (Baej and Worthington, 2014).

The remainder of the paper is structured as follows. Section 2 provides a brief review of Islamic finance, including its sources, principles and most-common products and services. Section 3 discusses the literature on consumer attitudes towards Islamic finance and Section 4 presents the theory and methodology we use for our analysis. Section 5 provides some descriptive statistics and Section 6 the main empirical results. The final section discusses these results and concludes the paper.

\section{Islamic finance}

Following Gait and Worthington (2014a), Islamic finance is a financial service or product principally implemented to comply with the main tenets of Sharia (or Islamic law). In turn, 
the main sources of Sharia are the Holy Quran, Hadith, Sunna, Ijma, Qiyas and Ijtihad. The Holy Quran is the book of revelation given to the Prophet Muhammad. Hadith is the narrative relating the deeds and utterances of Muhammad. Sunna refers to the habitual practice and behaviour of Muhammad during his lifetime. Ijma is the consensus among religion scholars about specific issues not envisaged in either the Holy Quran or the Sunna. Qiyas is the use of deduction by analogy to provide an opinion on a case not referred to in the Quran or the Sunna in comparison with another case referred to in the Quran and the Sunna. Finally, Ijtihad represents a jurists' independent reasoning relating to the applicability of certain Sharia rules on cases not included in either the Quran or the Sunna.

In brief, the principles of Islamic finance include the prohibition of Riba (usury or interest) and the removal of debt-based financing, the prohibition of Gharar, encompassing full information disclosure, the removal of asymmetric information in contracts, and the avoidance of risk-taking, and the exclusion of financing and dealing in 'sinful' activities and commodities (such as gambling, alcohol and pork). They also include an emphasis on risk sharing in business ventures, the desirability of materiality, such that a financial transaction requires a link to some real economic transaction, and the consideration of justice, such that a financial transaction should not lead to the exploitation of any party to the transaction (Gait and Worthington, 2014a).

In practice, these principles manifest themselves as a wide range of commercial products and services offered by Islamic financial institutions. These include Mudarabah, the provision of capital in return for a share of profits but where losses on funds lent are borne solely by the lender, Musharakah, where the provider of funds and the entrepreneur wholly share in the business, and Murabaha, where the financial institution purchases goods and services on behalf of a customer. Other products and services include Bai muajjall, deferred payments on products, Bai Salam, advance sale contracts for goods and services, Istisna, manufacturing contracts to cover work in progress, Ijarah, or operating lease financing, Takaful or Islamic insurance in the form of cooperative self-help schemes, and Quard Hassan, benevolent loans offered interest free. Islamic products and services also increasingly manifest themselves as mutual funds underpinned by investments in Sharia-compliant assets, including equity, but also Sukuk (Gait and Worthington, 2014a).

\section{Literature review}

Erol and El-Bdour (1989) and Erol et al. (1990) are considered the first studies of consumer attitudes towards Islamic banking. In general, there is much agreement between these on the 
high level of awareness of Islamic banking in Jordan and that a fast and efficient service and the bank's reputation were significant factors for the choice of a bank. However, religious motivation had no significant effect on the use of Islamic banking services. Omer (1992) surveyed 300 Muslims in the UK on their patronage and awareness of Islamic financing methods. The main finding was that a high level of ignorance prevailed among UK Muslims concerning the principles of Islamic finance. However, while ill informed, religious motivation still comprised the most significant factor in their strong preference for Islamic banking services.

Metwally (1996) also used factor analysis to study the attitudes of Muslims in three Arabic dual-banking systems (Kuwait, Saudi Arabia and Egypt) towards Islamic banking with follow on work in Metwally (2002, 2003). Similar to Omer (1992), religion was the primary factor in the choice of an Islamic banking institution. Regardless, and similarly to Erol and ElBdour (1989), Erol et al. (1990) and Haron et al. (1994) observed that Islamic bank consumers still rated the speed and efficiency of banking services near the top of their bank selection criteria. Haron et al. (1994) likewise highlighted the differences in the patronage of Islamic and conventional banks in their study of Muslims and non-Muslims in Malaysia. As in Erol and El-Bdour (1989) and Erol et al. (1990), factor analysis showed that religious motivation was not the primary reason for Muslims dealing with Islamic banks. The findings also suggested that while Malaysian Muslims and non-Muslims were aware of the existence of Islamic banks, they were usually uninformed of specific Islamic financing methods.

In Bahrain, Metawa and Almossawi (1998) concluded that the most important factors in determining the attitudes of Islamic bank consumers were religion followed by profitability. In Jordan, Naser et al. (1999) extended the early work by Erol and El-Bdour (1989) and Erol et al. (1990), but concluded that bank reputation and religious beliefs were the two most important factors motivating the use of Islamic banks services. And in Kuwait, Al-Sultan (1999) considered the attitudes of consumers towards the products and services offered by the interest-free Kuwait Finance House. In the same way as Metwally (1996), Al-Sultan (1999) confirmed that adherence to Islam was the primary motivating factor for Kuwaitis dealing with an Islamic bank. In Singapore, Gerrard and Cunningham (1997) also considered attitudes towards Islamic banking, though in the context of a banking system where no Islamic banks were yet present. While the results showed, not entirely expectedly, that non-Muslims were completely unaware of Islamic methods of finance, Muslims often fared little better. Once again, fast and efficient service and confidentiality were the primary motivations for bank selection. 
Later, Hamid and Nordin (2001) focused on the awareness of Malaysian consumers towards Islamic banking within the context of the wider promotion of Islamic education. They found that most Malaysians did not differentiate between Islamic and conventional bank products and services, though the majority had sufficient knowledge of the existence and services offered by Malaysian Islamic banks. Moreover, even though half of the respondents currently dealt with Islamic banks, they were still in need of additional understanding of Islamic bank products. Bley and Kuehn (2004) surveyed business students in the United Arab Emirates (Sharjah) on their knowledge of financial aspects of Islamic and conventional banks. The major finding was that Muslim students preferred Islamic banking services because of religious motivations. In Turkey, customer satisfaction with interest-free banking and bank selection criteria has been considered by Okumus (2005). The most important finding was that the majority of Islamic bank consumers responded that religion was the primary motivation in their use of Islamic products and services. A second motivation was that the Islamic financial institutions in question also offered conventional bank products and services.

Dusuki and Abdullah (2007) focused on the customers of two Islamic banks in Malaysia: the Bank Islamic Malaysia Berhad and Bank Muamalat Malaysia Berhad. Their findings are consistent with many earlier Islamic banking patronage studies where the quality of service delivery, including staff friendliness and competency and an efficient and speedy service were important factors in influencing bank selection. In addition, they also found that older, relatively well-educated and low and middle-income customers preferred Islamic banks.

Finally, in Australia (Adelaide), Rammal and Zurbruegg (2007) surveyed 300 Muslims regarding their awareness of Islamic banking products. Their results indicated that the majority of respondents are interested in and prepared to use Islamic methods of finance, but do not know how they function. In other words, even though most respondents have knowledge about the availability of Islamic financial products, they are still unaware of basic Islamic banking principals and methods. This finding is supported by much of the extant literature, including Okumus (2005), Bley and Kuehn (2004), Hamid and Nordin (2001), Naser et al. (1999), and Haron et al. (1994). However, Rammal and Zurbruegg (2007) countered that a lack of awareness and experience with halal (food permissible according to Islamic law) did not appear detrimental to consumer willingness to use these products. Somewhat more prosaically, the respondents also indicated the potential use of Islamic financial products as long as the bank also made automatic teller machine (ATM) and telephone banking available. 
Subsequent work on attitudes to Islamic finance in a variety of contexts over a range of products and services include Loo (2010), Lee and Ullah (2011), Echchabi and Olaniyi (2012), Ramdhony (2013), Demirguc-Kunt et al. (2013) and Gait and Worthington (2014b). Gait and Worthington (2008) provide a useful (but rather dated) review of the literature on individual, business firm, and financial institution attitudes to Islamic methods of finance.

\section{Theory and methodology}

We undertake our analysis based on the theory of reasoned action, first developed by Ajzen and Fishbein (Fishbein and Ajzen, 1975; Ajzen and Fishbein, 1980), comprising behavioural intention, attitude, and subjective norm. This theory suggests that a person's behavioural intention depends on the person's attitude about the behaviour and subjective norms, so that if a person intends to undertake some behaviour then it is likely that they will do it. Behavioural intention measures the relative strength of the intention to perform or undertake some behaviour, here Islamic methods of finance. Attitude consists of beliefs about the consequences of performing the behaviour multiplied by the evaluation of its consequences, here the positive and negative attributes of Islamic methods of finance. Lastly, subjective norm is the combination of perceived expectations from relevant individuals or groups along with the intention to comply with these expectations, here whether these groups approve or disapprove of Islamic methods of finance and the impact on the individual making the decision on behaviour. In general, the more favourable the attitude and the subjective norm, the stronger should be the person's intention to perform the behaviour in question (Hale et al., 2002).

We argue that both consumer and product attributes affect the attitude and subjective norm for Islamic finance. In terms of product attributes, we believe the Sharia principles involved in Islamic financial products and services determine how consumers react to these products. A key factor here is how Islamic financial products and services differ to those offered by conventional financial institutions. We also believe that the social and cultural environment as well as demographic, psychographic, and geographic conditions will shape consumer behaviour. For example, consumers may have different attitudes to Islamic finance depending not only on their level of knowledge, religious beliefs and past experience with an Islamic finance product or service, but also how they see themselves potentially engaging with the product or service (for example, as a depositor or a borrower). To evaluate this, we seek to link surveyed attitudes with observable characteristics of both the consumer and the 
Islamic financial product or service as a way to understand how this may assist or complicate the marketing of Islamic finance in our chosen context.

We designed a questionnaire to collect data from Libyan consumers. To ensure the speed of data collection, control of the sample, good flexibility, and reasonable cost, we collected the data through telephone interviews. The main advantages of this method of collection are that it allows the opportunity to reduce any potential confusion by the respondent on the questions asked and obtains a relatively high response rate. We selected the sample for Libyan consumers randomly in accordance with a 95 percent confidence level. The sample size of 385 was determined using a proportion $(\pi)$ of .05 (the safest possible assumption), a confidence level of $95 \%$ corresponding to a Z-value of 1.96 , and an error $(E)$ of 0.05 . The optimal sample size $N$ is then:

$$
N=\pi(1-\pi) Z^{2} / E^{2} \quad \mathrm{~N}=(0.5)(0.5)(1.96)^{2} /(0.05)^{2} \quad N=384.16
$$

Before undertaking the data collection, we interviewed a focus group, also through telephone interviews. This group comprised 20 (pre-screened) respondents representing about 5\% of the sample. We used these interviews to ensure the effectiveness and timeliness of the questionnaire for data collection.

Following the focus group interviews, we conducted the survey from December 2007 to February 2008. Regrettably, the ongoing civil unrest in Libya prevented the finalisation of this research until recently. We randomly selected respondents using systematic sampling. First, the population size is the telephone directory for Libya's four largest cities (Tripoli, Benghazi, Misratah and Al Murgub). The directory included 79,056 private phone numbers (i.e. $N=79,056)$ in these cities. Second, dividing $N$ by the sample size $n=385$, gives a sample interval of 205. Third, we selected a random number between 1 and 205 using a table of random numbers. As this number was 48, the sample consisted of elements 48, 253 (i.e. 48 + 205), 458 (i.e. $253+205$ ), 663 (i.e. $458+205$ ) and so on. Finally, using the telephone directory as a sampling frame, we ordered the elements alphabetically. When the number dialled was not successful, we used the next number on the same page.

In the first part of the questionnaire (available from the authors upon request in Arabic and English), the respondents were requested to indicate their knowledge about Islamic banks and their methods of finance. We used the second part of the questionnaire to gather the respondents' attitudes towards Islamic methods of finance. This study uses a seven-point scale from 1 to 7 where 1 is not important at all and 7 is very important for 16 statements that represent reasons for the use of Islamic methods of finance. The questionnaire collected 
information on the socioeconomic characteristics of the respondents in the final part of the questionnaire.

The methodology used to analyse the survey responses is as follows. First, we use descriptive analysis to examine the degree of awareness of Libyan consumers about Islamic methods of finance. Second, we then use factor analysis to identify the main factors that motivate Libyan consumers to apply Islamic methods of finance. Finally, we use discriminant analysis to determine which factors account for the most impact on consumer attitudes towards using Islamic methods of finance.

\section{Descriptive statistics}

Table 1 provides several descriptive statistics. Of the 385 respondents, 331 (85.9\%) are potential users of Islamic methods of finance. The respondents (household heads) are also overwhelmingly male: $92.9 \%$ of respondents are male and only $7.1 \%$ are female. According to Al-Nouri (1995, p. 331), Libyan boys are repeatedly reminded of the responsibilities awaiting them upon reaching adulthood, particularly their role as principal breadwinner, husband and father. However, girls are simply prepared for marriage, motherhood, and housekeeping. Accordingly, women in Libya (and many other Arabic countries) are still not readily welcomed into many aspects of economic life. This socio-cultural stance may account in part for the financial dependency of women in many Islamic countries (Al-Nouri 1993), as evidenced here.

\section{$<$ TABLE 1 HERE $>$}

Over two-thirds (71.6\%) of the respondents are aged from 36 to 55 years and some 45.9\% have attained an education level at the intermediate or secondary level, with about a quarter of respondents completing a university degree. Most of the interviewees (75.8\%) are public servants (i.e. work in the government sector) and only $10.6 \%$ are self-employed. About $54.6 \%$ of respondents have an average monthly income of Libyan Dinar (LYD) 200-300 and approximately 35.8\% have incomes of LYD301-400 (LYD/AUD1.1812). The majority of respondents (97.6\%) are Libyan nationals.

Table 1 also includes statistical tests of the equality of variances and means for the proportion of potential users and nonusers of Islamic finance for each socioeconomic characteristic. As shown, potential users of Islamic finance are more likely to be aged 46 to 55 years, with a high school, diploma, or university education, work in the public sector, earn between LYD301-400 per month and are Libyan nationals. Potential nonusers of Islamic 
finance are more likely to be less than 25 years of age, have a primary school education only, be self-employed, and earn less than LYD200 per month or more than 301LYD per month.

\section{Empirical results}

Table 2 summarises Libyan retail consumers' awareness of Islamic methods of finance. First, approximately $91.1 \%$ of all respondents have knowledge about the existence of Islamic banks. Second, 67.8\% of respondents know about Musharakah and Quard Hassan. Third, 21\% of respondents have practiced Quard Hassan. However, most respondents are uninformed regarding other Islamic financing methods such as Mudarabah, Morabahah, Bai muajjall, and Istisna.

\section{$<$ TABLE 2 HERE $>$}

The results in Table 2 suggest that most of the respondents who are aware of Islamic methods of finance are also potential users. More particularly, 92.8\% of 347 consumers are knowledgeable about the existence of Islamic banks, 93.8\% of the 261 knowledgeable consumers in Musharakah and Quard Hassan only, and 93.9\% of 82 consumers who practiced Quard Hassan only are potential users. In other words, most of the consumers who are generally unaware of Islamic finance (90.3\%) are not potential users. Therefore, and not surprisingly, awareness of Islamic methods of finance has a positive effect on potential use of Islamic methods of finance.

The respondents indicate their ranking of importance for 16 statements that represent beliefs and evaluated outcomes for the potential use of Islamic methods of finance on a sevenpoint scale. Table 3 details the means and standard deviations of the variable scores. The data in column 2 suggests that the primary motivations towards Islamic methods of finance are its interest-free nature and religious principles. In contrast, that Islamic banks provide industrial financing (Istisna) and deposits with Islamic bank realising a higher variable rate of return lie at the end of the list of motivations.

\section{$<$ TABLE 3 HERE $>$}

We perform factor analysis on the explanatory variables with the goal of data reduction. The data in the correlation matrix (not shown) indicates high correlations between the explanatory variables significant at the 0.01 level. This justifies the appropriateness of factor analysis to reduce these highly correlated variables to a smaller more manageable number of factors. However, investigation indicates that the coefficients on the diagonals of the anti- 
image correlation matrix are greater than 0.5 for each variable. Therefore, there is no need to eliminate any of the variables. We employ Bartlett's test of sphericity to test the null hypothesis that the explanatory variables are uncorrelated in the population. The test statistic (7750.584) and p-value $(<0.01)$ reject the null. The Kaiser-Meyer-Olkin measure of sampling adequacy is also calculated, yielding a value of 0.803 , meaning that all of the partial correlation coefficients are small compared to the ordinary correlation coefficients. This also indicates that it is reasonable to proceed with factor analysis. We find that the 16 explanatory variables can be reduced to just four with eigenvalues greater than one. These factors account for about $83.7 \%$ of the total variance.

Table 3 also includes the rotated factor matrix obtained by the varimax procedure. Factor 1 has large coefficients $(>0.5)$ on the five variables in bold in column 2. These are: (i) profit/loss sharing method allows you to invest or borrow on a fair basis, (ii) Islamic bank may help in collecting and distribution of Zakah, (iii) Islamic bank aims to serve Muslim communities, (iv) Islamic bank may contribute to the society‘s development, and (v) Islamic bank may help poor people with benevolent loans (Quard Hassan). We refer to this factor as "Community Service" as these perceptions most closely link financial services and the Islamic community.

Factor 2 has large coefficients on four variables in bold in column 3. These are (i) deposits with Islamic banks would realise a higher variable rate of return, (ii) Islamic bank’s cost of borrowing depends on the outcome of the business, (iii) Islamic bank may invest according to profit sharing method only (Mudarabah), and (iv) Islamic bank lends money according to profit/loss sharing method (Musharakah). As these motivations generally suggest the intention of firms to increase profits and reduce losses we refer to this factor as "Profitability”.

Factor 3 has high coefficients on four variables in bold in column 4. These are; (i) Islamic bank methods of finance are interest-free, (ii) Islamic bank provides Islamic methods of finance in accordance with Sharia, (iii) religious motivation for depositing with Islamic bank, and (iv) religious motivation for borrowing from Islamic bank. As these motivations indicate the consumer's willingness to comply with religious principles, we refer to this factor as "Religion”. Finally, factor 4 has high coefficients on four variables in bold in column 5 . These are: (i) Islamic bank provides lease financing (Ijarah), (ii) Islamic bank provides trade financing methods such as Morabahah and (iii) Islamic bank provides industrial financing (Istisna). As these variables indicate new methods of finance not offered by the conventional banking system they are referred to as "Unique services". 
These factor scores (Community Service, Profitability, Religion, and Unique Services) are now suitable for use in multivariate analysis. We divide the respondents into two groups: namely, those that are potential users of Islamic methods of finance and those that are not. The mean and standard deviation of the factor scores for these groups and all respondents (not shown) suggest that the two groups are most widely separated in terms of the value of factor score 1 (Religion) and 2 (Profitability) while the differences are smallest for factor scores 3 (Community Service) and 4 (Unique Services).

Wilks' Lambda (p-value in brackets) is the proportion of variance not explained by differences between the groups: Community Service $0.740(<0.01)$, Profitability 0.0900 $(<0.01)$, Religion $0.599(<0.01)$, and Unique Services $0.985(<0.01)$. Because all of these values are less than one, we can attribute most of the observed variability in factor scores to differences between the groups. The polled within-group correlation matrix also indicates relatively low (negative) correlations between the factor scores (Community Service and Profitability, -0.197; Community Service and Religion, -0.484; Community Service and Unique Services, -0.072; Profitability and Religion, -0.272; Profitability and Unique Services, -0.041 ; and Religion and Unique Services, -0.100 ).

Box's $M$ (F-statistic $=25.589$, p-value $=<0.01$ ) rejects the null hypothesis that the covariance matrices are equal. The eigenvalue (3.443) is quite large and accounts for $100 \%$ of the explained variance. The canonical correlation is another measure of the degree of association between the discriminant scores and the groups. The canonical correlation of the discriminant function is about 0.88 : the square of this shows that our model explains $77.4 \%$ of the variance of the dependent variable (potential use of Islamic methods of finance). Wilks' lambda associated with the discriminant function is 0.225 . This is the ratio of the withingroups sum of squares to the total sum of squares. This transforms to a chi-square value of 568.202, which is statistically significant at the 0.01 level with degrees of freedom equal to the number of factor scores. Therefore, it is acceptable to reject the null hypothesis that respondents who are potential users have the same average discriminant function score in the population.

\section{$<$ TABLE 4 HERE $>$}

The absolute magnitude of the standardized canonical discriminant function coefficients suggests that Religion (1.173), Community Service (1.050), and Profitability (0.717) are the most important factors discriminating between potential users and nonusers of Islamic methods of finance. Clearly, religion is the primary motivation for the potential use of Islamic 
methods of finance among retail consumers in Libya, closely followed by Community Service. We obtain another way to assess the relative importance of the predictors by examining the structure correlations between the values of the function and the values of the variables (not shown). This again indicates that Religion (0.441) is the most important factor indicating the potential use of Islamic methods of finance by Libyan retail consumers while Profitability (0.179) and Unique Services (0.066) are much less important. The classification results in Table 4 show that perceptions held by retail consumers toward Islamic methods of finance are crucial in determining potential usage, with $99.7 \%$ of potential users and $96.3 \%$ of potential nonusers correctly classified.

\section{Discussion and conclusion}

This study establishes that while Islamic finance is not yet formally practiced in Libya, most retail consumers have some knowledge about Islamic methods of finance. Interestingly, consumers are highly aware of Musharakah (full partnership) and Quard Hassan (interestfree loans). In contrast, other Islamic financing methods, such as Mudarabah, Morabahah, Bai muajjall and Istisna, are relatively unknown. The study also suggests that most respondents are potential users of Islamic methods of finance. Factor analysis, using principal components and varimax rotation, reduced the 16 explanatory variables to just four factors. These are community service, profitability, religion and unique services. Discriminant analysis indicates that the respondents rank religious motivation highest of their reasons for the use of Islamic methods of finance, followed by community service and then profitability. While our findings are generally consistent with those in the existing literature, notwithstanding being outside the Libyan context, we have employed a much more rigorous and detailed analysis than existing work to obtain our insights.

Clearly, a large number of socioeconomic and demographic characteristics of consumers are suggestive of the attitudes held by consumers to Islamic methods of finance. This can help marketers better target their products. For instance, out results indicate that religious motivations ranks highest in determining positive attitudes to Islamic methods of finance, and marketers should ensure that their products strictly comply with Sharia. This emphasises the role of Sharia boards, either industry or government appointed, in vetting and confirming the compliance of financial institutions and their products and services with Sharia. Nonetheless, it is also possible to use this knowledge to help guide efforts to change the outcomes of these attitudes in terms of affect and behaviour. However, as these issues generally relate to existing products, for which there were none at the time of analysis, we confine our comments to the 
changes in beliefs that underpin these attitudes. Unfortunately, although attempting to change beliefs is the obvious way to attempt attitude change, this is often difficult to achieve.

Several approaches to belief change may be useful in our chosen context. One way is to change the importance of beliefs. For example, as a predominately-Muslim country, the positive attitude to Islamic methods of finance arising from religious beliefs is already strong. However, it may be possible to strengthen these positive attitudes by advertising that the community service role of Islamic finance is also important. Most consumers already agree with this, but we can make the belief even stronger. Another way is to add beliefs. Consumers are less likely to resist the addition of beliefs so long as they do not conflict with existing beliefs. Thus, it will enhance the positive attitudes to Islamic finance by also including messages that these methods of finance also include a community service role and provide unique services. Lastly, attitude research has shown that consumers often tend to react more favourably to marketing that either admit something negative about the product (e.g., Islamic finance is Sharia compliant, but less profitable for depositors) or something positive about a competing product (e.g., conventional finance is more profitable, but cares less about the community). These two-sided appeals must contain overriding arguments why the sponsoring product is ultimately superior; that is, emphasizing but for Islamic methods of finance.

This study also indicates a number of directions for further research. First, despite the evolving literature on Islamic finance, much work remains undone on consumer behaviour using sophisticated choice modelling techniques and larger samples. Second, this work on attitudes to Islamic finance is in a specific national context. It would then be interesting to compare feedback from a survey administered in, say, a country with a predominately-Islamic finance system, to a country with a dual-finance system, and another at an early stage of the introduction of Islamic finance. Finally, one reason for the growth of Islamic finance worldwide has been the willingness of national governments with a sectarian-orientation to support its establishment. It is unknown what particular role these governments have played in attempting to modify the attitudes to Islamic finance alongside any direct or indirect support or encouragement to the institutions themselves.

\section{References}

Al-Nouri, Q. (1993), “Iraqi rural women’s participation in domestic decision-making”, Journal of Comparative Family Studies Vol. 24 No. 1, pp. 81-97.

Al-Nouri, Q. (1995), “University modernizing effects on Libyan family and culture”, Journal of Comparative Family Studies Vol. 26 No. 3, pp. 329-347. 
Al-Sultan, W. (1999), Financial characteristics of interest-free banks and conventional banks. PhD Thesis, University of Wollongong.

Ajzen, I. and Fishbein, M. (1980), Understanding Attitudes and Predicting Social Behaviour, Prentice-Hall, Englewood Cliffs, NJ.

Baej, Y.M. and Worthington, A.C. (2014) 'Prospects, barriers, and impediments to Islamic banking in Libya' in Worthington, A.C. (Ed.), Contemporary Issues in Islamic Finance: Principles, Progress, and Prospects, Nova, New York, pp. 109-116.

Bley, J. and Kuehn, K. (2004), “Conventional versus Islamic finance: student knowledge and perception in the United Arab Emirates”, International Journal of Islamic Financial Services Vol. 5 No. 4, pp. 1-13.

Demirguc-Kunt, A., Klapper, L. and Randall, D. (2013), “Islamic finance and financial inclusion: Measuring use of and demand for formal financial services among Muslim adults”, World Bank Development Research Group, Policy Research Working Paper No. 6642.

Dusuki, A. and Abdullah, N. (2007), “Why do Malaysian customers patronise Islamic banks?”, International Journal of Bank Marketing Vol. 25 No. 3, pp. 142-160.

Echchabi, A., and Olaniyi, O.N. (2012), “Malaysian consumers’ preferences for Islamic banking attributes”, International Journal of Social Economics Vol. 39 No. 11, pp. 859-874.

Erol, C. and El-Bdour, R. (1989), “Attitudes, behaviour and patronage factors of bank customers towards Islamic banks”, International Journal of Bank Marketing Vol. 7 No. 6, pp. 31-37.

Erol, C., Kaynak, E. and El-Bdour, R. (1990), "Conventional and Islamic banks: patronage behaviour of Jordanian customers”, International Journal of Bank Marketing Vol. 8 No. 4, pp. 25-35.

Fishbein, M. and Ajzen, I. (1975), Belief, Attitude, Intention, and Behaviour: An Introduction to Theory and Research, Addison-Wesley, Reading, MA.

Gait, A. and Worthington, A.C. (2008), “An empirical survey of individual consumer, business firm and financial institution attitudes towards Islamic methods of finance”, International Journal of Social Economics Vol. 35 No. 11, pp. 783-808.

Gait, A. and Worthington, A.C. (2014a), “A primer on Islamic finance”, in Worthington, A.C. (Ed.), Contemporary Issues in Islamic Finance: Principles, Progress, and Prospects, Nova, New York, pp. 7-30.

Gait, A. and Worthington, A.C. (2014b), "Business firm attitudes toward Islamic methods of finance”, in Worthington, A.C. (Ed.), Contemporary Issues in Islamic Finance: Principles, Progress, and Prospects, Nova, New York, pp. 85-96.

Gerrard, P. and Cunningham, J. (1997), “Islamic banking: a study in Singapore”, International Journal of Bank Marketing Vol. 15 No. 6, pp. 204-216.

Hale, J.L., Householder, B.J. and Greene, K.L. (2002), “The theory of reasoned action”, in Dillard, J.P. and Pfau, M. (Eds.), The Persuasion Handbook: Developments in Theory and Practice, Sage, Thousand Oaks, CA, pp. 259-286.

Hamid, A. and Nordin, N. (2001), “A study on Islamic banking education and strategy for the new millenniumMalaysian experience”, International Journal of Islamic Financial Services Vol. 2 No. 4, pp. 1-10.

Haron, S., Ahmad, N. and Planisek, S. (1994), "Bank patronage factors of Muslim and non-Muslim customers”, International Journal of Bank Marketing Vol. 12 No. 1, pp. 32-40.

International Financial Services Research (2010), “Islamic finance 2010”, available at: http://www.londonstockexchange.com/specialist-issuers/islamic/downloads/ifsl-research.pdf (accessed 24 April 2014).

Lee, K-H. and Ullah, S. (2011), “Customers’ attitudes toward Islamic banking in Pakistan”, International Journal of Islamic and Middle Eastern Finance and Management Vol. 6 No. 4, pp. 131-145.

Loo, M. (2010), (2010), “Attitudes and perceptions towards Islamic banking among Muslims and non-Muslims in Malaysia: implications for marketing to Baby Boomers and X-Generation, International Journal of Arts and Sciences Vol. 3 No. 13, pp 453-485.

Metawa, S. and Almossawi, M. (1998), "Banking behaviour of Islamic bank customers: perspectives and implications”, International Journal of Bank Marketing Vol. 16 No. 7, pp. 299-315. 
Metwally, M. (1996), “Attitudes of Muslims towards Islamic banks in a dual-banking system”, American Journal of Islamic Finance Vol. 6 No. 1, pp. 11-17.

Metwally, M. (2002), “The impact of demographic factors on consumers' selection of a particular bank within a dual banking system: a case study”, Journal of International Marketing and Marketing Research Vol. 27 No. 1, pp. 35-44.

Metwally, M. (2003), "Attitudes of consumers in developing countries towards use of credit cards: the case of the state of Qatar”, Journal of International Marketing and Marketing Research Vol. 28 No. 2, pp. 83-96.

Naser, K., Jamal, A. and Al-Khatib, K. (1999), "Islamic banking: a study of customer satisfaction and preference in Jordan”, International Journal of Bank Marketing Vol. 17 No. 3, pp. 135-150.

Okumus, H. (2005), “Interest-free banking in Turkey: a study of customer satisfaction and bank selection criteria”, Journal of Economic Cooperation Vol. 26 No. 4, pp. 51-86.

Omer, H (1992). The implication of Islamic beliefs and practice on Islamic financial institutions in the UK, $\mathrm{PhD}$ Thesis, Loughborough University.

Rammal, H. and Zurbruegg, R. (2007), “Awareness of Islamic banking products among Muslims: the case of Australia”, Journal of Financial Services Marketing Vol. 12 No. 1, pp. 65-74.

Ramdhony, D. (2013), “Islamic banking awareness attitudes and bank selection criteria”, International Journal of Humanities and Applied Sciences Vol. 2, No. 2, pp. 1-7.

Smith, J., Terry, D., Manstead, A., Louis, W., Kotterman, D. and Wolfs, J. (2008), “The attitude-behaviour relationship in consumer conduct: the role of norms, past behaviour, and self-identity”, Journal of Social Psychology Vol. 148 No. 3, pp. 311-333. 
Table 1.

Sample characteristics

\begin{tabular}{|c|c|c|c|c|c|c|c|c|c|c|c|}
\hline \multirow[t]{2}{*}{ Variables } & & \multicolumn{2}{|c|}{$\begin{array}{l}\text { All respondents } \\
\quad(n=385)\end{array}$} & \multicolumn{2}{|c|}{$\begin{array}{l}\text { Potential user } \\
\quad(n=331)\end{array}$} & \multicolumn{2}{|c|}{$\begin{array}{l}\text { Not a potential } \\
\text { user }(n=54)\end{array}$} & \multicolumn{2}{|c|}{$\begin{array}{l}\text { Equality of } \\
\text { variances }\end{array}$} & \multicolumn{2}{|c|}{$\begin{array}{l}\text { Equality of } \\
\text { means }\end{array}$} \\
\hline & & Freq. & $\%$ & Freq. & $\%$ & Freq. & $\%$ & F-test & $\mathrm{p}$-value & t-test & p-value \\
\hline \multirow[t]{3}{*}{ Sex } & Male & 358 & 92.9 & 306 & 92.4 & 52 & 96.3 & 4.53 & 0.03 & -1.29 & 0.19 \\
\hline & Less than 25 years & 9 & 2.3 & 3 & 0.9 & 6 & 11.1 & 94.11 & $<0.01$ & 2.34 & 0.02 \\
\hline & 26 to 36 years & 79 & 20.5 & 53 & 16.0 & 26 & 48.1 & 45.82 & $<0.01$ & 4.49 & $<0.01$ \\
\hline \multirow[t]{5}{*}{ Age } & 36 to 45 years & 123 & 31.9 & 110 & 33.2 & 13 & 24.1 & 9.96 & $<0.01$ & -1.42 & 0.15 \\
\hline & 46 to 55 years & 153 & 39.7 & 148 & 44.7 & 5 & 9.3 & 482.20 & $<0.01$ & -7.33 & $<0.01$ \\
\hline & More than 55 years & 21 & 5.6 & 17 & 5.2 & 4 & 7.4 & 1.79 & 0.18 & 0.68 & 0.49 \\
\hline & No education & 9 & 2.3 & 9 & 2.7 & 0 & 000 & 11.08 & $<0.01$ & 1.15 & 0.25 \\
\hline & Primary school & 47 & 12.2 & 29 & 8.7 & 18 & 33.4 & 63.54 & $<0.01$ & 3.41 & $<0.01$ \\
\hline \multirow{6}{*}{$\begin{array}{l}\text { Highest } \\
\text { level of } \\
\text { education }\end{array}$} & High school & 94 & 24.4 & 87 & 26.2 & 8 & 14.8 & 26.21 & $<0.01$ & -2.55 & 0.01 \\
\hline & Secondary school & 61 & 15.8 & 45 & 13.6 & 16 & 29.6 & 26.22 & $<0.01$ & 2.44 & 0.01 \\
\hline & Diploma & 116 & 30.1 & 107 & 32.3 & 8 & 14.8 & 51.27 & $<0.01$ & -3.22 & $<0.01$ \\
\hline & University & 54 & 14.0 & 51 & 15.3 & 4 & 7.4 & 18.84 & $<0.01$ & -2.64 & $<0.01$ \\
\hline & Postgraduate & 4 & 1.2 & 4 & 1.2 & 0 & 0.0 & 2.69 & 0.10 & -0.81 & 0.41 \\
\hline & Public sector & 292 & 75.8 & 285 & 86.1 & 7 & 12.9 & 0.24 & 0.62 & -14.25 & $<0.01$ \\
\hline \multirow{4}{*}{$\begin{array}{l}\text { Employment } \\
\text { status }\end{array}$} & Private sector & 46 & 11.9 & 39 & 11.8 & 7 & 12.9 & 0.23 & 0.62 & 0.24 & 0.80 \\
\hline & Self-employed & 41 & 10.6 & 4 & 1.2 & 37 & 68.5 & 550.88 & $<0.01$ & 10.50 & $<0.01$ \\
\hline & Retired & 6 & 1.7 & 3 & 0.9 & 3 & 5.6 & 26.35 & $<0.01$ & 1.45 & 0.15 \\
\hline & Less than LYD200 & 17 & 4.4 & 17 & 5.1 & 0 & 0.0 & 13.00 & $<0.01$ & -4.22 & $<0.01$ \\
\hline \multirow{3}{*}{$\begin{array}{l}\text { Monthly } \\
\text { income }\end{array}$} & LYD201 to 300 & 211 & 54.8 & 201 & 60.8 & 10 & 18.5 & 79.54 & $<0.01$ & -7.06 & $<0.01$ \\
\hline & LYD301 to 400 & 138 & 35.8 & 109 & 32.9 & 29 & 53.7 & 6.38 & $<0.01$ & 2.83 & $<0.01$ \\
\hline & More than LYD400 & 19 & 5.0 & 4 & 1.2 & 15 & 27.8 & 428.96 & $<0.01$ & 4.29 & $<0.01$ \\
\hline Nationality & Libyan & 376 & 84.9 & 327 & 98.8 & 49 & 90.7 & 54.54 & $<0.01$ & 1.99 & 0.05 \\
\hline
\end{tabular}

Notes: Tests of equality of variances and means are for the proportion of potential users and nonusers of Islamic finance by variable. Levene's test of equality of variances determines whether the test for equality of means assumes equal or unequal variances. Significant test statistics and their p-values in bold. 
Table 2.

Awareness and practice of Islamic methods of finance

\begin{tabular}{|c|c|c|c|c|c|c|c|}
\hline \multirow{2}{*}{ Variable } & \multirow[b]{2}{*}{$\begin{array}{l}\text { Knowledge } \\
\text { and practice }\end{array}$} & \multicolumn{2}{|c|}{$\begin{array}{c}\text { All } \\
\text { respondents }\end{array}$} & \multicolumn{2}{|c|}{$\begin{array}{c}\text { Potential } \\
\text { user }\end{array}$} & \multicolumn{2}{|c|}{$\begin{array}{c}\text { Not a potential } \\
\text { user }\end{array}$} \\
\hline & & Freq. & $\%$ & Freq. & $\%$ & Freq. & $\%$ \\
\hline \multirow{2}{*}{$\begin{array}{l}\text { Knowledge of Islamic } \\
\text { banking }\end{array}$} & Yes & 347 & 90.1 & 322 & 92.8 & 25 & 7.2 \\
\hline & No & 38 & 9.9 & 9 & 23.7 & 29 & 76.3 \\
\hline \multirow{3}{*}{$\begin{array}{l}\text { Knowledge of Musharakah } \\
\text { and Quard Hassan }\end{array}$} & Yes & 261 & 67.8 & 245 & 93.8 & 16 & 6.2 \\
\hline & No & 34 & 8.8 & 4 & 11.8 & 30 & 88.2 \\
\hline & Yes & 82 & 21.3 & 77 & 93.9 & 5 & 6.1 \\
\hline \multirow{2}{*}{$\begin{array}{l}\text { Past practice of Quard } \\
\text { Hassan }\end{array}$} & No & 297 & 77.0 & 250 & 84.2 & 47 & 15.2 \\
\hline & Not applicable & 31 & 8.1 & 3 & 9.7 & 28 & 90.3 \\
\hline
\end{tabular}




\section{Table 3.}

Attitudes to Islamic methods of finance and rotated component matrix

\begin{tabular}{|c|c|c|c|c|c|c|}
\hline \multirow{2}{*}{ Variables } & \multirow[b]{2}{*}{ Mean } & \multirow[b]{2}{*}{ Std. dev. } & \multicolumn{4}{|c|}{ Components } \\
\hline & & & 1 & 2 & 3 & 4 \\
\hline Islamic bank methods of finance are interest-free. & 5.1039 & 1.5594 & 0.287 & 0.306 & 0.816 & 0.065 \\
\hline Islamic bank provides Islamic methods of finance in accordance with Sharia. & 4.6234 & 1.8059 & 0.355 & -0.089 & 0.811 & 0.298 \\
\hline Deposits with Islamic banks would realise a higher variable rate of return. & 3.8078 & 1.4449 & -0.042 & 0.946 & 0.040 & 0.226 \\
\hline Religious motivation for depositing with Islamic bank. & 4.1792 & 1.5483 & 0.271 & 0.044 & 0.919 & 0.063 \\
\hline Islamic bank's cost of borrowing depends on the outcome of the business. & 4.1610 & 1.3010 & 0.153 & 0.592 & 0.084 & -0.016 \\
\hline Religious motivation for borrowing from Islamic bank. & 4.4286 & 1.5396 & 0.227 & 0.012 & 0.911 & 0.091 \\
\hline Islamic bank may invest according to profit sharing method only (Mudarabah). & 3.9117 & 1.4710 & -0.051 & 0.943 & 0.031 & 0.213 \\
\hline Islamic bank lends money according to profit/loss sharing method (Musharakah). & 3.9455 & 1.4876 & -0.047 & 0.940 & 0.040 & 0.213 \\
\hline Profit/loss sharing method allows you to invest or borrow on a fair basis. & 4.1714 & 1.6713 & 0.690 & 0.240 & 0.250 & 0.258 \\
\hline Islamic bank may help in the collection and distribution of Zakah. & 3.9948 & 1.7882 & 0.836 & -0.006 & 0.226 & 0.147 \\
\hline Islamic bank aims to serve Muslim communities. & 3.9325 & 1.4561 & 0.882 & -0.100 & 0.237 & 0.127 \\
\hline Islamic bank may contribute to society’s development. & 4.1922 & 1.6502 & 0.943 & -0.136 & 0.212 & 0.034 \\
\hline Islamic bank provides lease financing (Ijarah). & 3.8935 & 1.5500 & 0.144 & 0.281 & 0.084 & 0.897 \\
\hline Islamic bank provides trade financing methods such as Morabahah. & 3.9143 & 1.3827 & 0.218 & 0.053 & 0.265 & 0.850 \\
\hline Islamic bank provides industrial financing (Istisna). & 3.8000 & 1.4046 & 0.067 & 0.553 & 0.026 & 0.739 \\
\hline Islamic bank may help poor people with benevolent loans (Quard Hassan) & 4.8312 & 1.6724 & 0.725 & 0.329 & 0.397 & 0.013 \\
\hline
\end{tabular}


Table 4.

Classification results

\begin{tabular}{llrrr}
\hline \multirow{2}{*}{ Classification } & Predicted group membership & Total \\
\hline & \multicolumn{1}{c}{ Groups } & Potential users & $\begin{array}{c}\text { Not potential } \\
\text { users }\end{array}$ & $\begin{array}{c}\text { Potential } \\
\text { users }\end{array}$ \\
\hline Number & Potential users & 330 & 1 & 331 \\
& Not potential users & 2 & 52 & 54 \\
Percentage of group & Potential users & 99.7 & 0.3 & 100.0 \\
& Not potential users & 3.7 & 96.3 & 100.0 \\
\hline
\end{tabular}

